\title{
THE CASE FOR LARGE $(M>7)$ EARTHQUAKES FELT IN THE UK IN HISTORICAL TIMES
}

\author{
R.M.W. Musson \\ Seismology and Geomagnetism Programme, British Geological Survey, West \\ Mains Road, Edinburgh EH9 3LA, UK \\ Tel: +44-131-650-0205 \\ Fax: +44-131-667-1877 \\ email: R.Musson@bgs.ac.uk
}

\begin{abstract}
Evidence from seismic and bathymetric surveys along the passive margin of NW Europe indicates that there are a number of features suggestive of large earthquakes having occurred in geologically recent times, although the exact timing of these events is difficult to establish. It might be thought that, although such large earthquakes may have occurred, for example, in immediate postglacial times in response to rapid isostatic readjustment, no earthquake in the UK area in historical times has exceeded a value of around 5.7 Mw. However, in past interpretations of regional seismicity, the possibility that some known historical earthquakes were in fact passive margin events has not really been canvassed. A large, distant, offshore earthquake is likely to be felt only at moderate strength over well-populated areas without any observable damage concentration. In a period when documentation of earthquakes is always sparse, such an occurrence is likely to lead to vague reporting that will not be easily interpretable. Looking at the historical record with this in mind, it is possible to identify some earthquakes that are at least compatible with an offshore interpretation, as shown in a series of case studies. However, in no case is such an interpretation the only one viable. Also, some cases that initially appear to be potentially passive margin events can in fact be discounted. While there is no unequivocal evidence for large earthquakes having occurred on the NW European passive margin in historical times, neither can the possibility be rejected, and examination of the record shows one event in particular (in 1508) which may be a large passive margin event. Thus the regional maximum magnitude could possibly be larger than has hitherto been assumed.
\end{abstract}

\section{Keywords}

Passive margins, historical earthquakes, maximum magnitude, seismic hazard, offshore earthquakes, water fluctuations.

\section{Introduction}

The issue of maximum credible magnitude, important in seismic hazard analysis, has always been a difficult subject to handle in intraplate areas, where the seismic cycle is longer than the historical record. In this paper the issue of the possibility of large earthquakes in the UK is examined, with particular emphasis on the possibility that such a large earthquake may actually have occurred in historical times without being recognised from the earthquake record. 
In considering this topic in the general sense, the occurrence of large ( $7 \mathrm{Mw})$ earthquakes in quiet seismic areas (such as the 1989 Tennant's Creek, Australia earthquake or the 1993 Latur, India earthquake, to name but two) naturally raises speculation as to whether such events can occur in other low seismicity areas. The estimation of maximum magnitude cannot proceed on the basis of fault length, since the existence of ancient major faults (like the Great Glen Fault in Scotland) does not mean that these faults could reactivate along their whole length in a major earthquake in present day tectonic circumstances, quite different from those of the time they formed. One approach is through palaeoseimic investigation (e.g. (Camelbeeck and Meghraoui, 1996),(Camelbeeck and Meghraoui, 1998),(Camelbeeck et al., 2001)) though this can be difficult in glaciated areas. Attempts at palaeoseismic studies in Scotland (Davenport and Ringrose, 1985; Fenton and Ringrose, 1992) have been considered unconvincing by Stewart et al. (2001).

Examining the historical record for the British Isles, Ambraseys and Jackson (1985) write:

"The seismicity of the UK is clearly different from that of eastern USA or W Africa in that either (i) no earthquakes of $M \geq 6.0$ occur, or (ii) 700 years is not long enough to reveal such events in the UK, whereas 100 years is more than adequate in the eastern USA and W Africa. ... Is there anywhere on the continents seismically quieter than the UK?"

In some respects the comparison is unfair, since the eastern USA is over four times as large as the UK, and western Africa is larger still. One could easily find parts of the eastern USA or western Africa of equivalent size to the UK that have comparable or lower levels of seismic activity.

Nevertheless, the lack of even moderately large earthquakes with onshore epicentres in Britain is rather striking. Taking the period 1570-2005 one can distinguish eighteen events of magnitude 5.0-5.4 ML in Britain with epicentres onshore or just offshore to the west (i.e. excluding events in the North Sea and English Channel). The number of events larger than $5.4 \mathrm{ML}$ in the same area is zero. The Gutenberg-Richter $b$ value that one would derive from earthquakes $\geq$ $5.0 \mathrm{ML}$ in this area (admittedly eighteen is a very small sample) is 1.8. However, in the same period, there are four earthquakes $>5.4 \mathrm{ML}$ in the English Channel and North Sea (south of $60^{\circ} \mathrm{N}$ ). If one assumes that there is no difference between Great Britain and the offshore extension to the south and east as regards producing earthquakes larger than $5.4 \mathrm{ML}$, then the probability of all four larger events occurring in the offshore area by chance is about 0.015 .

Before 1570 it is very difficult to estimate magnitudes. Thus some medieval earthquakes such as 20 February 1247 and 11 September 1275 were most likely over $5 \mathrm{ML}$, but it would stretching slender evidence to attempt to categorise whether they were larger than 5.4 ML (Musson, 1994).

On the available information, therefore, it does appear that there is a significant lack of earthquakes of $5.5 \mathrm{ML}$ and over in mainland UK in the last 400 years (this is about $5.2 \mathrm{Mw}$ ). The purpose of this paper is to explore the possibility that there may actually be much larger earthquakes in the historical record of the UK, but which are hard or impossible to recognise because they have offshore epicentres. The reader is warned in advance that much of this paper is highly speculative. Given the difficulty of the subject matter this is unfortunately inevitable. 


\section{Passive margin seismicity}

The first comprehensive study of intraplate seismicity worldwide, with a view to distinguishing areas most at risk from unexpectedly large events, was made by Sykes (1978). After a lengthy review of global intraplate seismicity, he concluded that a particular locus of large-magnitude intraplate events was on the passive margins of continents. He particularly considered that the intersection of passive margins and oceanic transform fracture zones marked locations of concern. He argued that such fracture zones initiated at the earliest stages of oceanic rifting at the sites of pre-existing weaknesses in the continental crust, and that these weaknesses continued to act as possible earthquake sources even when oceanic rifting was well advanced.

A subsequent major study of worldwide intraplate seismicity was commissioned by the Electric Power Research Institute in the US, which confirmed Sykes's findings that passive margins are significant, but without the emphasis on the intersection with oceanic fracture zones (Johnston et al., 1994). In a summary in Johnston (1989), it is noted that

"Of [the] eight largest SCI [Stable Continental Interior] earthquakes, seven occur at passive margins or in extended crust resulting from margin formation."

A classic example is the 18 November 1929 Grand Banks earthquake (7.2 Mw). This occurred off the coast of Newfoundland in an area with no previous or subsequent seismicity barring aftershocks of the 1929 earthquake itself. The earthquake triggered a large submarine slide on the continental slope, which in turn produced a damaging tsunami which killed 28 (Smith, 1966; Stewart, 1979; Fine et al., 2005). It was also widely felt over the onshore area (Smith, 1966). Sykes (1978) notes that the epicentre is near the intersection of the passive margin with the Newfoundland Fracture Zone.

This raises two questions with respect to north-west Europe: could an earthquake similar to the 1929 Grand Banks earthquake occur on the north-west European continental margin? And is there any evidence that such a thing might have occurred already? The question is particularly pertinent given recent concerns about whether tsunami warning systems should be implemented in the North Atlantic in the wake of the 26 December 2004 Sumatran earthquake (Kerridge, 2005).

\section{Geological evidence for large passive margin earthquakes near Britain}

That significant earthquakes have happened on the north-west European margin at some time in the past has already been mooted in the literature with regard to the triggering of submarine slope failures (Paul and Jobson, 1987; Baltzer et al., 1998; Holmes et al., 1998; Jackson et al., 1999). Submarine landslides are common features along passive margins (Embley and Jacobi, 1977; Embley, 1982; Mienert et al., 2003; Canals et al., 2004; Hühnerbach et al., 2004) and at least fifteen large slides or mass flows can identified along the NW European margin from $50^{\circ} \mathrm{N}$ to $70^{\circ} \mathrm{N}$, including the massive Storegga slide (Bugge et al., 1987; Mienert and Weaver, 2003) as shown in Figure 1. That large submarine slides may be due to earthquake triggering is well known (Hampton et al., 1996); the case of 1929 Grand Banks has already been mentioned, and some other cases are reviewed by Embley (1982). In the case of Europe, the relationship between seismicity and slides is ambiguous; it is suggested by Mienert et al. (2003) that earthquake triggering may not be the most important reason for slides. One other mechanism that has been suggested, for instance, is that slides may be triggered by escape of gas hydrates (Bugge et al., 1987; Vogt and Jung, 
2002). Recent studies, though, incline towards viewing earthquakes as the most likely external triggering factor (Canals et al., 2004; Sultan et al., 2004). Holmes et al. (1998) consider that earthquakes may have triggered slide movements on the Barra Fan, and Baltzer et al. (1998) conclude that at least one earthquake (probably just before or during the early Devensian, i.e. around 70,000 years BP) was responsible for triggering the debris flows of the Sula Sgeir Fan. Strachan and Evans (1991) consider that earthquake triggering was the most likely explanation for the sediment failure below the Geikie escarpment. (These locations are close together; only the Geikie Escarpment is named on Figure 1).

The discussions of seismicity in these references unsurprisingly make most reference to known modern seismicity in the area, which is limited and of small magnitude. The existence of a few events like the 13 April 1980 Hebrides Terrace Seamount $(4.0 \mathrm{mb})$ shows that the area is not entirely aseismic (Jacob et al., 1983). Paul and Jobson (1987) estimate that an earthquake of magnitude 6 could have caused failure on the Hebrides slope. Baltzer et al. (1998) then go on to say that a magnitude 6 might have taken place during times of major isostatic adjustment (i.e. the early Devensian). This is no doubt a sound argument; but by analogy with other passive margins, and given a long period of observation, it is not actually necessary to invoke greater isostatic adjustment in order to allow for the possibility of a large earthquake. The same is true of some the examples discussed in the COSTA Project (Canals et al., 2004); seismicity is considered to be strongly indicated as a causative factor in several examples, and where examination of modern and historical data shows very low activity, it is suggested that seismicity may have been elevated in immediate post-glacial times. In fact, rare passive margin earthquakes are a possible factor even in periods where seismicity is not elevated as a result of deglaciation.

The most recent of these slides is probably the Afen Slide in the Faroe-Shetland Channel, which is not older than about 2880 years BP (Wilson et al., 2003, 2004), putting it within range of the historical period, though of course accurate dating is not possible. The morphology of the slide suggests that it was due to triggering by an earthquake, possibly associated with the Victory Transfer Zone (Canals et al., 2004; Sultan et al., 2004; Wilson et al., 2004), and an attempt has been made to model the effects of earthquake loading on slope stability in the area (Jackson et al., 2004).

Thus the existence of the various slides shown in Figure 1 is evidence in favour of large earthquakes having occurred on the passive margin at least some time in the past.

Two other pieces of evidence can also be cited. The first is the existence of two deformation ridges off the continental slope south-west of the Celtic Sea. These were first shown by Masson and Parson (1983) and are also marked on Figure 1. The southern feature is described by Masson and Parson (1983) as a complex faulted monocline, with crustal shortening accommodated by two zones of reverse faulting. Superficially, they resemble coseismic ridges which can develop in cases where faulting does not break through the surface in a fault scarp, as in the case of the Reelfoot Scarp, which was created by the 1812 New Madrid earthquake in Tennessee (Russ, 1979). They could therefore reflect large earthquakes. They are not easy to date. Masson and Parson (1983) consider that they must be later than the Early to Middle Eocene boundary. It has been suggested that they may be later than this (Tate 2005, pers. comm.) but this is unproven.

The second is the existence of an apparent sea-floor-cutting fault on the northern flank of the Wyville-Thompson Ridge (Tate et al., 1999). This is shown on a seismic section (Figure 3 in Tate et al., 1999) as a steep, south dipping fault cutting the sea bed. Uplift of the Wyville-Thompson Ridge started in the late 
Eocene and continued intermittently throughout the Oligocene, and possibly until Recent times (Tate et al., 1999). This north-bounding fault is possibly the only known instance of seabed fault displacement in UK waters, and it does rather suggest palaeoseismic evidence of a large earthquake. Precise dating is not possible; it may be recent, but this is debatable. Other faults have been identified in the vicinity of the Afen Slide, with offsets of several metres, displacing Quaternary sediments and occasionally reaching the sea floor (Canals et al., 2004).

To sum up: it is probable, from physical evidence, that large earthquakes have occurred on the NW European passive margin, at least since Devensian times, and possibly more recently. The remainder of the paper will address the possibility that such an event may actually have occurred in historical times, and that such a large earthquake may be sitting in published earthquake catalogues without anyone having been able to recognise it.

\section{Likely effects of a large offshore earthquake}

We can begin by considering what might be expected to be observed and reported if a large earthquake occurred on the NW Europe passive margin, similar in magnitude to the 1929 Grand Banks earthquake. In Figure 2, estimated isoseismals are plotted for such an event, based loosely on the isoseismals of the 1929 Grand Banks event (Smith, 1966) evened out to remove ellipticality, and with a notional epicentre near the Geikie Escarpment on the edge of the Hebrides Shelf. Obviously, actual isoseismals could vary in different ways, and these are intended only to be indicative. If such an earthquake were to have occurred in the late modern period when communications were good, one might expect the isoseismals would be such as could be reconstructed quite well from macroseismic data, as has been the case with other large British earthquakes. However, the impact on the historical record in earlier centuries could be expected to be different.

The area over which damage would be observed, within the isoseismals 6 and 7 EMS (European Macroseismic Scale), are in the remote north and north-west of Scotland. In this area, before the $18^{\text {th }}$ century, the population consisted of subsistence farmers who spoke Gaelic rather than English, and were illiterate. The Gaelic language in Scotland never had a literary tradition in the way that other Celtic languages such as Welsh and Irish did have. Communications with the rest of Britain were very poor; there were no roads until the $18^{\text {th }}$ century when the first roads into the Scottish highlands were built for military purposes. Thus, no information could be expected to come out of this area about the damage that occurred.

This can be illustrated by the case of the earthquake of 8 November 1608. A plot of places from which reports exist (Figure 3) shows a dramatic divide along the "Highland Line" - the geological divide between the mountain country of the north of Scotland and the lowlands of the Central Valley. South of this line there are many reports; to the north there are none. This is nothing to do with the distribution of earthquake effects, but entirely to do with the distribution of literacy.

Returning to Figure 2, over the rest of the British Isles the shaking would vary from strong (5 EMS) but not damaging in the Scottish cultural centres (Stirling, Edinburgh, St Andrews, Glasgow) to weak (3 EMS) over most of the wealthiest (the southern) parts of England.

Therefore, for the period before the $17^{\text {th }}$ century (and one might except the later $16^{\text {th }}$ century as well) the sort of report that one might expect to survive would be along the lines of information that an earthquake was felt over a very wide area, but without any description of effects such as damage (since there would be no 
notable effects in the areas from which one might expect reports to come). One might also find it reported that the earthquake was stronger in Scotland; however, generally historical reporting is less good for Scotland than it is for England, partly due to the loss of documents in the violence of the Scottish Reformation.

In fact, there are a number of earthquakes that more or less meet this description, especially for the medieval period. Clearly, though, in the case of an earthquake that is mentioned in chronicles as "felt throughout England" with no further detail, there are plenty of alternative explanations, including (a) that the epicentre was in a remote part of England or Wales; (b) that the chronicler felt it not worth mentioning that the cottages of mere peasants were thrown down; (c) "throughout England" is an exaggeration for "here and in the next town as well".

In the next section some particular case studies are considered in detail (see Table 1).

\section{Case studies}

It is all too easy, in considering a subject such as this, to extend an idea too far and start to interpret all obscure earthquake reports as possible large distant events, when there are much more straightforward explanations that don't require large earthquakes.

A general consideration is the difficulty of interpreting any historical offshore earthquake from sparse macroseismic data on a single coast. In the absence of other information, one can usually posit either a small earthquake just offshore, or a larger one further out to sea, and there may be no constraints on how one interprets this other than the general rule that small earthquakes are inherently more common phenomena than large ones. In assigning epicentres to historical offshore earthquakes in the UK earthquake catalogue (Musson, 1994), the standard practice was to adopt the closest credible epicentre to shore and thus the smallest probable magnitude.

An interesting case in point is the earthquake of 4 January 1879. This was weakly felt on the island of Unst, which is the most northerly of the Shetland Isles. This was the only place in the UK where it was felt, but it was also felt in Norway (Kolderup, 1913) at Flesje, on the other side of the North Sea. We can thus be certain that this was a moderately large earthquake between Shetland and Norway, most likely in the Viking Graben, and with an estimated magnitude of around 4.8 ML. Now, there are also a number of other reports of earthquakes felt only on Unst at around the same period, and these are not matched with Norwegian records. Are these other largish events in the North Sea which were less strong to the east? Or similar events to the north or west of the Shetlands? Or small local earthquakes? It is not possible to tell, although given that seismicity in the Viking Graben and South Møre Basin is much greater than any other seismicity in the area, one is inclined to suspect that these solitary reports from the Shetlands (often from lighthouses) represent earthquakes $>4.5 \mathrm{ML}$ at some distance to the east and north-east of the point of observation.

\section{August 1089}

This earthquake will stand for some other medieval cases. Like so many medieval events in the UK, the available information is brief and unsatisfactory. The account in the Anglo-Saxon Chronicle (Ingram, 1823), one of the major sources of information for the $11^{\text {th }}$ century, reads

"There was also over all England much earth-shaking on the third day before the ides of August ..." 
The fullest account is by the chronicler William of Malmesbury (Stevenson, 18536), who writes:

“... a great earthquake terrified all England with a horrid spectacle; for all the buildings were lifted up, and then settled again as before."

The same information from these two accounts is repeated with some minor variation in various other chronicles, evidently with much copying. These include the two surviving monastic chronicles from Scotland, the Holyrood Chronicle (Anderson, 1938) and the Melrose Chronicle (Stevenson, 1839). The significance of this is open to question. The MS source of the Holyrood Chronicle is $13^{\text {th }}$ century, and the entries for the $11^{\text {th }}$ century need not reflect local information. The Holyrood entry is very terse. The entry in the Melrose Chronicle reads,

"There occurred a very great earthquake throughout the whole of England about the third hour of the day."

The Melrose Chronicle is only a contemporary narrative after 1172, and for the $11^{\text {th }}$ century it is clearly based on English sources. Thus one notes that the "whole of England" is mentioned without any reference to Scotland.

All one has for this earthquake, therefore, is that it was widely felt throughout England, and buildings were shaken but not (so far as is noted) damaged. The mention in two Scottish chronicles is inconclusive, as the transmission into these two sources is most likely just a product of the copying of English sources without regard for local interest. This does not rule out the possibility that the earthquake was indeed also felt in Scotland.

This earthquake is thus more or less consistent with Figure 2, and so are a number of other medieval events that are similarly reported. In this particular case, the use of words like "great" and "terrified" suggest higher intensities in England than are shown in Figure 2. It could be speculated, though, that in the case of a large, distant earthquake, long-period effects on castles and cathedrals and other monumental structures could produce alarm even at considerable distances.

Of course, there are other possible explanations, and it does not seem possible that one could ever resolve the issue.

For Ireland, there are no mentions of this earthquake in any of the Irish Chronicles. The situation with regard to medieval Ireland should be commented on. In the Annals of Ulster (Balé and Purcell, 2003) there are a number of references to earthquakes before $1000 \mathrm{AD}$ which are the earliest mention of any earthquake in the British Isles. However, given accounts that say no more than "earthquake in Ireland" one cannot be sure whether these really refer to earthquakes as we use the word, since the term was also used for landslides and other similar phenomena. Given the fact that Ireland is one of the most aseismic countries in the world, it would not be surprising if most of these records were actually not earthquakes. It is also not surprising that few other mentions of earthquakes appear at all in the Irish records of the post-millenial period. In fact there are just two. The earthquake of 20 February 1247 is mentioned by both the Annals of Inisfallen (Färber, 2000a) and the fragmentary annals (Färber, 2000b). The former misdates the year as 1249 and states that it was felt in Ireland and Wales; the latter describes it as affecting Ireland, Scotland and Wales. The other Irish earthquake for this period is dated 1269; there are no details, and the source, Dowling's Annals (Butler, 2003) is not contemporaneous.

The 1247 earthquake is the only earthquake before the $19^{\text {th }}$ century that one can say was certainly felt in England, Scotland, Ireland and Wales. It was particularly strong, and even damaging, in Wales, and there seems little doubt that this was a Welsh earthquake and one of the largest known in Wales. 


\section{September 1508}

The source material for this earthquake has already been published and discussed at length in Musson (2004) and will be summarised only briefly here. There are only three sources, none of them contemporary. Two are Scottish and one is English, and the English one may have used one of the Scottish ones. The combined information yields the following points:

- The earthquake was reportedly felt over all England and Scotland.

- People were much frightened.

- The shock lasted six minutes.

- The earthquake particularly shook churches.

As in the previous case, we have an earthquake with a large felt area, this time explicitly including Scotland as well as England, plus a description of shaking buildings without any mention of damage. It is interesting to note that churches were most affected; this again might be consistent with the effect of long-period shaking on the highest buildings around. It would probably be dangerous to try and read much into the estimate of six minutes duration, as such estimates are usually unreliable. Enormously exaggerated durations ("the shock lasted for half an hour") can be interpreted as referring to the main shock plus several aftershocks. Six minutes is not gross exaggeration, and may be taken as indicating at least that what was perceived was not a short sharp shock - again, consistent with a distant event.

The fact that Scottish sources here have prime place does lead one to infer that the shock was stronger in Scotland than in England. There are not many interpretations that are consistent with the evidence, slender though it is. (Musson, 1994) treats this earthquake as a probable Northern North Sea earthquake, analogous to that of 24 January 1927; this possibility is compared to the passive margin hypothesis in Musson (2004). There is no information forthcoming from Norway, but given the historical period, this is not very likely anyway.

Probably, of all events in the UK earthquake catalogue, this is the one that conforms best to the pattern of Figure 2. What is missing is any report from Ireland. If it were known that the earthquake had also been felt in Ireland, the implication that this was likely to have been a large passive margin event would be strong. Historical earthquakes in Ireland were investigated 30 years ago by Richardson (1975), and his report does not include any entry for 1508. No more recent search of the Irish archives for earthquake data has been undertaken. Considering known sources for this period, the Annals of Ulster make no mention of any earthquake, but at this period it is a record of raids and deaths of eminent people (Balé and Purcell, 2003). The same is true of the Annals of Loch Cé (Färber, 2005), the Annals of Connacht (Bambury, 2001) and the Annals of the Four Masters (Ryan, 2002). None of these chronicles mention the Welsh earthquake of July 1534 which was definitely felt in Dublin (Ware, 1662).

\section{January 1607}

In January of 1607 a sudden inundation in the Bristol Channel flooded an area of countryside around the town of Burnham-on-Sea to a depth of 3-4 m, and caused damage at Barnstaple, Bridgewater, Bristol, Glastonbury and Kingston Seymour (Horsburgh, 2006); South Wales was also affected (Figure 4). There was some loss of life. It has been suggested (Bryant and Haslett, 2003; Disney, 2005) that this flooding was due to a tsunami, though no earthquake is reported as having been felt on this date. An earthquake is known to have affected Barnstaple and 
the adjacent area on 12 May 1607 (Musson, 1989) and it would be surprising if this small local event were known and a more generally felt larger one very close in time was not.

Therefore, if this event was a tsunami, it must have been caused by an earthquake sufficiently far offshore not to have been felt in England. One can posit an epicentre south-west of the Celtic Sea such that a large earthquake might be felt weakly in south-west Ireland but not elsewhere. And the likelihood of finding felt reports from south-west Ireland at this period is very low.

Furthermore, although the edge of the Celtic sea is a very low seismicity area, one anomalous earthquake has been observed there on 17 February 1980, with a reported magnitude of $4.5 \mathrm{ML}$ (according to the agency LDG - Laboratoire de Détection et de Géophysique, France, as reported in the bulletin of the International Seismological Centre). This seems to show that some structure in this area is capable of reactivation. The event is too poorly recorded for a focal mechanism to be possible. Alternatively, this could possibly be an explosion from underwater disposal of munitions, but the records seen do not suggest that this is likely.

Consequently, one cannot rule out a passive margin tsunamigenic earthquake as impossible on seismological grounds. Whether the 1607 event was a tsunami or not is another matter. The alternative is that the inundation was a storm surge. Horsburgh (2006) has shown that contemporary weather records mention prolonged high winds before 20 January 1607, and that other parts of England also suffered from flooding. Tidal conditions for 20 January 1607 can also be calculated, and they were particularly high (Horsburgh, 2006). Thus the conditions were in place for a storm surge event, and consequently there is no need to invoke any tsunami to explain the historical observations.

It is concluded, therefore, that there was no large passive margin earthquake on 20 January 1607.

\section{6}

The remotest inhabited place in the British Isles used to be the island of St Kilda (it was evacuated in the mid $20^{\text {th }}$ century), $170 \mathrm{~km}$ west of the Scottish mainland. In historical times the island was home to a small community of illiterate subsistence farmers who lived almost without any contact with the outside world. Given that the seismicity of mainland Britain is not that well known for the $17^{\text {th }}$ century, it would seem amazing that one could know anything about an earthquake in this period felt on St Kilda, yet by strange chance this is the case.

In 1697 an estates administrator called Martin Martin, an aspiring naturalist with a university education, travelled to St Kilda to make notes on natural history. In the course of his excursion, he learnt from the islanders that they had felt an earthquake in 1686 (Martin, 1716; Musson, 1998). Since Martin worked on the Outer Hebrides, the nearest islands east of St Kilda, and seems to have been unaware of this 1686 earthquake previously, it may be taken that St Kilda was the only place where it was felt. Thanks to the chance visit of Martin to St Kilda, and the fact that he published what he learnt there, we know today, against all odds, that this earthquake took place.

This earthquake presents an extreme case of the coastal problem. The only report is from a speck of an island surrounded by sea, and one cannot tell whether the epicentre was north, south, east or west, never mind how far from shore it was. One can guess it was less likely to be to the east, as this would put it closer to the Outer Hebrides and the mainland. 
Clearly this cannot have been a large earthquake of $6 \mathrm{Mw}$ or greater, as then it would certainly have been more widely observed. However, it shows that, despite contemporary aseismicity, the Atlantic waters west and north-west of Scotland have produced earthquakes in the past large enough to be felt. It also shows how much of a lottery is the preservation of historical records of such events.

\section{May 1847}

In the course of the $19^{\text {th }}$ century, a number of anomalous tidal fluctuations in the south-west of England were reported, some of which resemble weak tsunamis, and which were considered to be earthquake-related at the time. These were particularly chronicled by Richard Edmonds (Edmonds, 1846, 1856, 1860, 1869) and all have recently been listed and reviewed by Dawson et al. (2000). Some of these may be due to storm surges. It is curious that so many are reported from Cornwall and yet not from south-west Ireland or from Brittany.

One such event will be considered in detail here, which is particularly significant as it was accompanied by an actual earthquake report. This is the event of 23 May 1847. On this day strange tidal fluctuations were observed along the coast of Cornwall and Devon, as far east as Plymouth and also in the Scilly Isles. The maximum amplitude was from 1.0-1.6 m (Edmonds, 1869). In the Scilly Isles a strange noise was heard, as if underground (Falmouth Packet 5 June 1847 p8). The previous evening a slight earthquake was felt by many people in the Penzance district (Falmouth Packet 29 May 1847 p8).

This is another case of an offshore event where one has a choice between adopting a small near-shore solution or a larger event further away. How close to the Scilly Isles was the epicentre? The very fact of a marine disturbance makes a small near-shore earthquake less likely. The generally flat bathymetry of the coastal waters around England make slumping-induced events unlikely, so either the marine disturbance was not seismic, or the earthquake was probably distant, and therefore fairly large. One can hypothesise a large earthquake on the passive margin south-west of the Celtic Sea with an elliptical felt area that reached to the Scilly Isles without touching Ireland or France (Figure 5).

There are still two problems. The first is the Penzance earthquake the night before, which appears must have been a local event the timing of which just before a larger offshore earthquake was complete coincidence. This is the solution proposed by Musson (1989). The other is the duration of the marine disturbance. According to Edmonds (1869) the fluctuation began as early as $05 \mathrm{~h}$ near Penzance, reached a peak at $17 \mathrm{~h}$, and at Plymouth did not peak until between $20 \mathrm{~h}$ and $21 \mathrm{~h}$. This duration is too long to be credible for a tsunami. Even if, say, the time of the onset was misreported, the fact that the disturbance continued all day with varying magnitude and peaked late, rather than peaking with one of the first waves, is inconsistent with what one expects from a tsunami and suggests instead some meteorological phenomenon. In this case, both earthquake reports are coincidences.

What happened on 23 May 1847 is thus enigmatic.

\section{Discussion and conclusions}

From what is known about patterns of intraplate seismicity, the possibility of a large earthquake on the passive margin of north-west Europe has to be considered. Physical evidence on the sea floor suggests that such events have occurred in the past, at least in geologically recent time, since it may be the case that at least some of the observed slides were earthquake-triggered. 
Asking the question as to whether such an event could have occurred in historical time without this having been recognised from existing reports, the answer appears to be yes. There exist poorly documented earthquakes that were widely felt with no evidence that they were strong or damaging in what might be the epicentral area. Until now, the question as to whether any of these might be a large passive margin earthquake has not been raised. There is no conclusive evidence that any of these earthquakes are passive margin events; one can only say that it is conceivable that they might be. The best candidate is probably the earthquake of 19 September 1508; but even with this one there are alternative interpretations that are also consistent with the evidence.

Positive identification might be achieved if evidence from Ireland could be obtained, but the limitations of the documentary record from Ireland before the $18^{\text {th }}$ century makes this unlikely. A sequence of chance events preserved a piece of oral history that an earthquake was felt in Antrim (Northern Ireland) around 1600 by Sir Hugh Clotworthy. A woman was told that this happened before she was born; in her old age she passed the information to someone else. Because an earthquake was felt in Dublin in 1690, that someone (Sir Thomas Molyneux) thought to include the information in a letter to his brother; the letter survived and was published in a university magazine in the mid $19^{\text {th }}$ century (Marsh, 1841). There is no other information on this earthquake (unless it is a distant report of the 23 July 1597 earthquake felt over much of the north of Scotland). It is only by this chain of happenstance that there is any information at all, and if information from Ireland c. 1600 survives only through luck, one cannot read much into the absence of reports from Ireland in 1508. The story of the 1686 earthquake, given previously, is another example of how the historical seismologist is dependent on luck.

What are the consequences of all this? Firstly, the judgement of Ambraseys and Jackson (1985) previously quoted is in need of revision, at least to the extent that large magnitude earthquakes may have occurred in the British Isles in the last 1000 years - we are just not able to recognise them for what they are with the evidence on hand. To generalise from this that an earthquake with magnitude $>6$ $\mathrm{Mw}$ or even $7 \mathrm{Mw}$ is possible in mainland Britain (which would have some implications for seismic hazard) is another matter.

If we assume that large magnitude earthquakes can affect the British Isles, but only from the passive margin, the effect on hazard assessment for onshore structures would be very limited. In intraplate areas in general, probabilistic seismic hazard assessment (PSHA) is not very sensitive to decisions made about maximum magnitude, except perhaps at very long return periods. This is because even if one allows the possibility of large earthquakes, they must be such rare events that they contribute little to the hazard compared with more moderatesized earthquakes that are much more common, and may still produce high ground motion values through scatter. If one introduces large magnitude earthquakes that are also at a considerable distance offshore, the effect is infinitesimal.

The implications are much more significant with respect to offshore hydrocarbon exploration, as a large earthquake could either directly damage offshore installations, or cause damaging submarine slope failure. However, this danger is already recognised (Baltzer et al., 1998).

The other potential issue is tsunami hazard. One cannot tell how rare large passive margin earthquakes in north-west Europe are, beyond saying that the earthquakes themselves are rare, and that should one occur, the chances of it being also tsunamigenic are low. Therefore the conditional probability of a tsunami occurring could be very low indeed. Even so, given the danger to human life, and the fact that tsunami warning systems can be fairly inexpensive if 
combined with other monitoring systems, it may still be advantageous to pursue such a system for the north-east Atlantic (Kerridge, 2005).

\section{Acknowledgements}

This paper grew out of a presentation to the International Seminar in Memory of Jean Vogt (1929-2005), and I would like to pay tribute to Jean Vogt as one of the outstanding contributors to the study of historical seismology. As mentioned above, discoveries in historical seismology often depend on serendipity, and Jean Vogt had a remarkable gift for discovering key documents in unpromising archive collections. This paper also draws upon my contribution to a study commissioned by the Department for Environment, Food and Rural Affairs (Defra) on tsunami risk to the UK, published as (Kerridge, 2005). I would like in addition to thank Michael Tate of Tate Exploration Consultants Ltd for drawing my attention to some of the offshore evidence cited in this paper, and also Kevin Horsburgh of Proudman Oceanographic Laboratory for discussions of the 1607 event; also Dave Long and Ken Hitchen of BGS for helpful discussions on various aspects of this work. Comments from Michel Cara and Gottfried Grünthal improved the quality of this paper. This paper is supported by the Natural Environment Research Council and is published with the permission of the Executive Director of the British Geological Survey (NERC).

\section{References}

AMBRASEYS, N N, and JACKSON, D D. 1985. Long-term seismicity in Britain. 49-66 in Earthquake engineering in Britain. (London: Thomas Telford.)

ANDERSON, M O (editor). 1938. A Scottish chronicle known as the chronicle of Holyrood. Third Series. (Edinburgh: Scottish History Society.)

BALÉ, M, and PURCELL, E (editors). 2003. The Annals of Ulster. (Cork: University College Cork.)

BAltZer, A, Holmes, R, and LONG, D. 1998. Debris flows on the Sula Sgeir Fan, NW of Scotland. 105-115 in Geological processes on continental margins:

Sedimentation, mass-wasting and stability. STOKER, M S, EVANS, D, and CRAMP, A (editors). Geological Society Special Publication, 129. (London: Geological Society.)

BAMBURY, P (editor). 2001. Annals of Connacht. (Cork: University College Cork.)

BRYANT, E A, and HASLETT, S K. 2003. Was the AD 1607 coastal flooding event in the Severn Estuary and Bristol Channel (UK) due to a tsunami? Archaeology in the Severn Estuary, Vol. 13, 163-167.

Bugge, T, Befring, S, Belderson, R H, EIdVIn, T, JANSen, E, KenYon, N H, HOLTEDAHL, H, and SEJRUP, H P. 1987. A giant three-stage submarine slide off Norway. Geo-Marine Letters, Vol. 7, 191-198.

BUTLER, R (editor). 2003. Short annals of Ireland (by Thaddeus Dowling). (Cork: University College Cork.)

Camelbeeck, T, Martin, H, Vanneste, K, Verbeeck, K, and Meghraoul, M. 2001. Morphometric analysis of active normal faulting in slow-deformation areas: Examples in the Lower Rhine Embayment. Netherlands Journal of Geosciences, Vol. 80, 95-107.

CAmelbeeCK, T, and MeghraOUI, M. 1996. Large earthquakes in northern Europe more likely than once thought. Eos, Vol. 77, 405,409. 
CAMELBEECK, T, and MeghrAOUI, M. 1998. Geological and geophysical evidence for large paleoearthquakes with surface faulting in the Roer Graben (northwest Europe). Geophysical Journal International, Vol. 132, 347-362.

Canals, M, Lastras, G, Urgeles, R, Casamor, J L, Mienert, J, Cattaneo, A, DE BATIST, M, HAFLIDASON, H, IMBO, Y, LABERG, J S, LOCAT, J, LONG, D, LONGVA, O, MASSON, D G, SULTAN, N, TRINCARDI, F, and BRYN, P. 2004. Slope failure dynamics and impacts from seafloor and shallow sub-seafloor geophysical data: Case studies from the COSTA project. Marine Geology, Vol. 213, 9-72.

DAVENPORT, C A, and RINGROSE, P S. 1985. Fault activity and palaeoseismicity during quaternary time in Scotland - Preliminary studies. 143-156 in Earthquake engineering in Britain. (London: Thomas Telford.)

Dawson, A G, Musson, R M W, Foster, I D L, and Brunsden, D. 2000. Abnormal historic sea-surface fluctuations, SW England. Marine Geology, Vol. 170, 59-68.

DISNEY, M. 2005. Britain had its own big waves -400 years ago. Times, 4 January. London.

EDMONDS, R. 1846. An account of an extraordinary movement of the sea in Cornwall, in July 1843, with notices of similar movements in previous years, and also of earthquakes which have occurred in Cornwall. Report of the British Association of the Advancement of Science, Vol. 38, 112-121.

EDMONDS, R. 1856. An account of an earthquake shock on the 30th May 1855; and of an extraordinary agitation of the sea on the 6th June 1855; in Penzance; with observations on the cause of the latter. Edinburgh New Philosophical Journal, Vol. 3, 280-285.

EDMONDS, R. 1860. An account of the extraordinary agitations of the sea in the West of England, on the 25th and 26th June, and the 4th October 1859; with notices of the earthquake shocks in Cornwall on the 11th of November 1858, and the 21st October 1859. Edinburgh New Philosophical Journal, Vol. 12, 1-15.

EDMONDS, R. 1869. On extraordinary agitations of the sea not produced by winds or tides. Transactions of the Devonshire Association, Vol. 3, 144-152.

EMBLEY, R W. 1982. Anatomy of some Atlantic margin sediment slides and some comments on ages and mechanisms. 189-214 in Marine slides and other movements. SAXOV, S, and NIEUWENHUIS, J K (editors). (New York: Plenum Press.)

EMBLEY, R W, and JACOBI, R. 1977. Distribution and morphology of large submarine sediment slides and slumps on Atlantic continental margins. Marine Geotechnology, Vol. 2, 205-228.

FÄRBER, B (editor). 2000a. Annals of Inisfallen. (Cork: University College Cork.)

FÄRBER, B (editor). 2000b. MacCarthaigh's Book. (Cork: University College Cork.)

FÄRBER, B (editor). 2005. Annals of Loch Cé AD 1014-1590. (Cork: University College Cork.)

FENTON, C H, and RINGROSE, P S. 1992. Late Quaternary movement along the Kinloch Hourn Fault, Inverness-shire. 54-60 in Neotectonics in Scotland: A field guide. C.H., F (editor). (Glasgow: University of Glasgow.)

Fine, I V, RABINOVICH, A B, BoRnhold, B D, Thomson, R E, and KULIKOV, E A. 2005. The Grand Banks landslide-generated tsunami of November 18, 1929: Preliminary analysis and numerical modelling. Marine Geology, Vol. 215, 45-57. 
HAMPtON, M A, LEE, H J, and LoCAT, J. 1996. Submarine landslides. Reviews of Geophysics, Vol. 34, 33-59.

HOLMES, R, LONG, D, and DODD, L R. 1998. Large-scale debrites and submarine landslides on the Barra Fan, west of Britain. 67-79 in Geological processes on continental margins: Sedimentation, mass-wasting and stability. STOKER, M S, EvANS, D, and CRAMP, A (editors). Geological Society Special Publication, 129. (London: Geological Society.)

HORSBURGH, K. 2006. Bristol Channel flooding in 1607, Weather, in press.

HÜHNERBACH, V, MASSON, D G, and PARTNERS OF THE COSTA-PROJECT. 2004. Landslides in the North Atlantic and its adjacent seas: An analysis of their morphology, setting and behaviour. Marine Geology, Vol. 213, 343-362.

INGRAM, J (editor). 1823. The Saxon Chronicle, $A D 1$ to AD 1154. (London: Longman, Hurst, Rees, Orme and Brown.)

JACKSON, P D, GUNN, D A, and LONG, D. 2004. Predicting variability in the stability of slope sediments due to earthquake ground motion in the AFEN area of the western UK continental shelf. Marine Geology, Vol. 213, 363-378.

JACKSon, P D, GunN, D A, Stoker, M, Holmes, R, HobBs, P R N, LONG, D, WALKER, A B, and MUSSON, R M W. 1999. Impact of earthquake ground motion on the stability of slope sediments using existing ground models. British Geological Survey, WN/98/21C.

JACOB, A W B, NeILSON, G, and WARD, V. 1983. A seismic event near the Hebrides Terrace Seamount. Scottish Journal of Geology, Vol. 19, 287-296.

JOHNSTON, A C. 1989. The seismicity of stable continental interiors. Earthquakes at North-Atlantic passive margins: Neotectonics and postglacial rebound of the NATO Advanced Research Workshop, 1988 May 9-13, Vordingborg, Denmark, Kluwer, 299-328.

Johnston, A C, Coppersmith, K J, KANTER, L R, and CoRnell, C A. 1994. The earthquakes of stable continental regions. Electric Power Research Institute, TR102261-V4.

KERRIDGE, D J (editor). 2005. The threat posed by tsunami to the UK. Study commissioned by Defra Flood Management. (London: HMSO.)

KolDERUP, C F. 1913. Norges jordskjælv. Bergens Museum Aarbok 8.

MARSH, H. 1841. Sir Thomas Molyneux, Bart., M.D., F.R.S. Dublin University Magazine, Vol. 18, 305-327.

MARTIN, M. 1716. A description of the Western Isles of Scotland. (London: Bell.)

MASSON, D G, and PARSON, L M. 1983. Eocene deformation on the continental margin SW of the British Isles. Journal of the Geological Society of London, Vol. 140, 913-920.

Mienert, J, Berndt, C, LABerg, J S, and Vorren, T O. 2003. Slope instability of continental margins. 179-193 in Ocean Margin Systems. WEFER, G, BILLET, D, HebBeln, D, JoRgensen, B B, SCHLÜTER, M, and WEERING, T C E v (editors). (New York: Springer Verlag.)

MIENERT, J, and WEAVER, P (editors). 2003. European margin sediment dynamics: Side-scan sonar and seismic images. (Berlin: Springer.)

Musson, R M W. 1989. Seismicity of Cornwall and Devon. British Geological Survey, WL/89/11. 
Musson, R M W. 1994. A catalogue of British earthquakes. British Geological Survey, WL/94/04.

Musson, R M W. 1998. Historical seismicity of the Western Frontiers area. British Geological Survey, WL/98/26.

Musson, R M W. 2004. Early seismicity of the Scottish Border region. Annals of Geophysics, Vol. 47, 1827-1848.

PAUL, M A, and JOBSON, L M. 1987. On the geotechnical and acoustic properties of sediments from the British Continental Margin west of the Hebrides.

Department of Civil Engineering, Heriot-Watt University.

RICHARDSON, M. 1975. Seismicity of Ireland. Electricity Supply Board.

RUSS, D P. 1979. Late Holocene faulting and earthquake recurrence in the Reelfoot Lake area, northwestern Tennessee. Geological Society of America Bulletin, Vol. 90, 1013-1018.

RYAN, E (editor). 2002. Annals of the Four Masters. (Cork: University College Cork.)

SMITH, W E T. 1966. Earthquakes of Eastern Canada and adjacent areas, 19281959. Publications of the Dominion Observatory, Vol. 32, 87-121.

STEVENSON, J (editor). 1839. Chronica de Mailros (A. D. 731-1275). (Edinburgh: Bannatyne Club.)

STEVENSON, J (editor). 1853-6. Church historians of England. (London: Rolls Series.)

STEWART, G S. 1979. The Grand Banks earthquake of November 18, 1929 and the Bermuda earthquake of March 24, 1978 - A comparative study in relation to their intraplate location. Eos, Vol. 60, 312.

Stewart, I S, FiRTh, C R, Rust, D J, Collins, P E F, and FIRTH, J A. 2001. Postglacial fault movement and palaeoseismicity in western Scotland: A reappraisal of the Kinloch Hourn fault, Kintail. Journal of Seismology, Vol. 5, 307328.

STRACHAN, P, and EVANS, D. 1991. A local deep-water failure on the Northwest Slope of the UK. Scottish Journal of Geology, Vol. 27, 101-111.

Sultan, N, Cochonat, P, Canals, M, Cattaneo, A, Dennielou, B, Haflidason, H, LABERG, J S, LONG, D, MIENERT, J, TRINCARDI, F, URgeles, R, VorRen, T O, and WILSON, C K. 2004. Triggering mechanism of slope instability processes and sediment failures on continental margins: A geotechnical approach. Marine Geology, Vol. 213, 291-321.

SYKES, L R. 1978. Intraplate seismicity, reactivation of preexisting zones of weakness, alkaline magmatism, and other tectonism postdating continental fragmentation. Reviews of Geophysics and Space Physics, Vol. 16, 621-688.

TATE, M P, DodD, C D, and GRANT, N T. 1999. The Northeast Rockall Basin and its significance in the evolution of the Rockall-Faroes/East Greenland rift system. 391-406 in Petroleum Geology of Northwest Europe. FLEET, A J, and BOLDY, S A R (editors). (London: Geological Society.)

VOGT, P R, and JUNG, W-Y. 2002. Holocene mass wasting on upper non-polar continental slopes - due to post-glacial ocean warming and hydrate dissociation? Geophysical Research Letters, Vol. 29, 9.

WARE, J. 1662. Rerum Hibernicarum Henrico Octavo Regnante, Annales. (Dublin: Crook.) 
WILSON, C K, LONG, D, and BULAT, J. 2003. The Afen Slide - a multistage slope failure in the Faroe-Shetland Channel. 317-324 in Submarine mass movements and their consequences. LOCAT, J, and MIENERT, J (editors). Advances in natural and technological hazards research series. (Dordrecht: Kluwer.)

WILSON, C K, LONG, D, and BULAT, J. 2004. The morphology, setting and processes of the Afen Slide. Marine Geology, Vol. 213, 149-167. 


\section{Table Captions}

Table 1

Synopsis of case studies. 
Tables

\begin{tabular}{l|ll}
\hline \multicolumn{1}{c|}{ Date } & Entry in Musson (1994) & Revised conclusion \\
\hline 11 August 1089 & England, probably $>$ 4ML & No change \\
19 September 1508 & Viking Graben? & $\begin{array}{l}\text { Possibly passive margin } \\
\text { event }\end{array}$ \\
20 January 1607 & Not considered & Not an earthquake \\
1686 & Not considered & $\begin{array}{l}\text { Epicentre near St Kilda, } \\
\text { probably }>3.5 \mathrm{ML}\end{array}$ \\
23 May 1847 & Below magnitude & No change \\
\hline
\end{tabular}

Table 1 


\section{Figure Captions}

Figure 1

Regional map showing principal geological features referred to. Stippled area marks extent of major submarine slides. 1: Storegga Slide; 2: Afen Slide; 3:

Approximate position of fault on north side of Wyville Thompson ridge; 4: Areas of late or post Eocene compression; 5: Approximate location of edge of continental shelf (incompletely shown). White star: location of the Hebrides Seamount earthquake of 13 April 1980. Black star: location of earthquake of 17 February 1980.

Figure 2

Likely extent of isoseismals from a $7 \mathrm{Mw}$ earthquake located on the edge of the Hebrides Shelf.

Figure 3

Distribution of felt reports of the 8 November 1608 Comrie earthquake in relation to topography. The dashed line indicates the "Highland Line", which also coincides with the Highland Boundary Fault. The only place to the north of this from which the earthquake is reported is Aberdeen, which lies in the Englishspeaking lowlands east of the Gaelic-speaking Highlands. Star indicates the position of the epicentre.

Figure 4

Water symbol: places affected by the inundation of 20 January 1607. Lozenge: felt reports of the 12 May 1607 Barnstaple earthquake.

Figure 5

Sketch showing a notional (and not very likely) reconstruction of the 23 May 1847 event. Stippled area is the continental slope; lozenges indicate earthquake felt reports. 


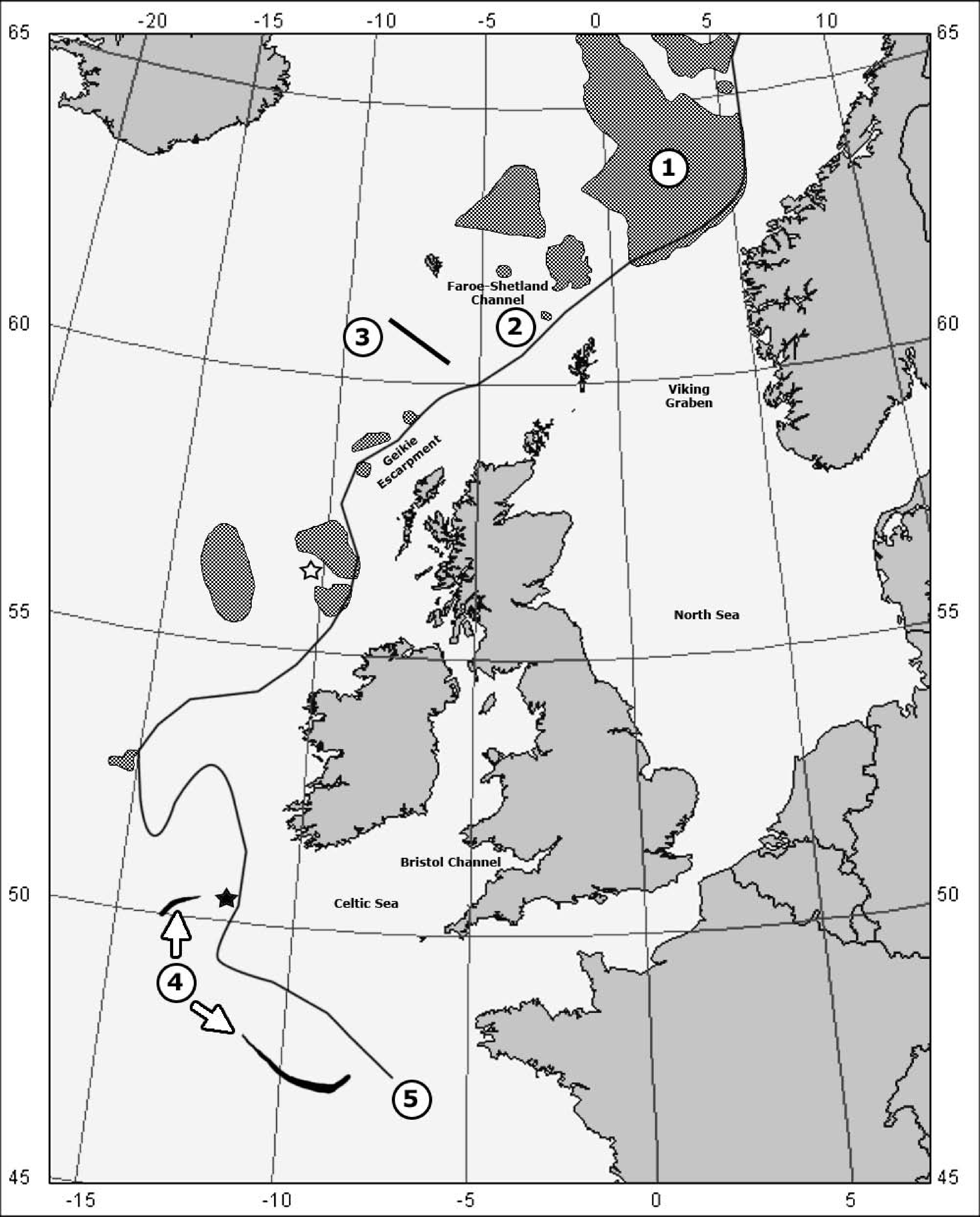




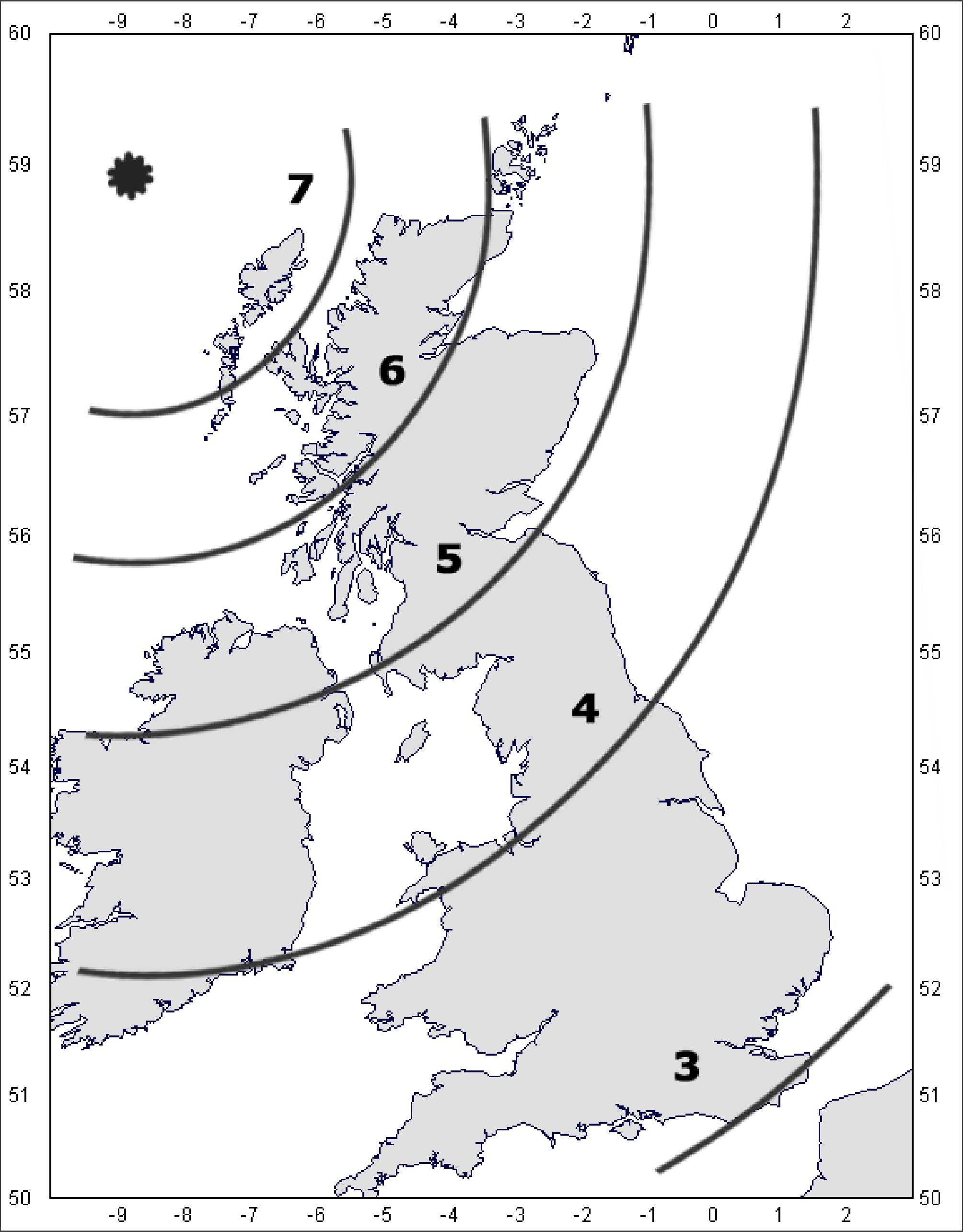




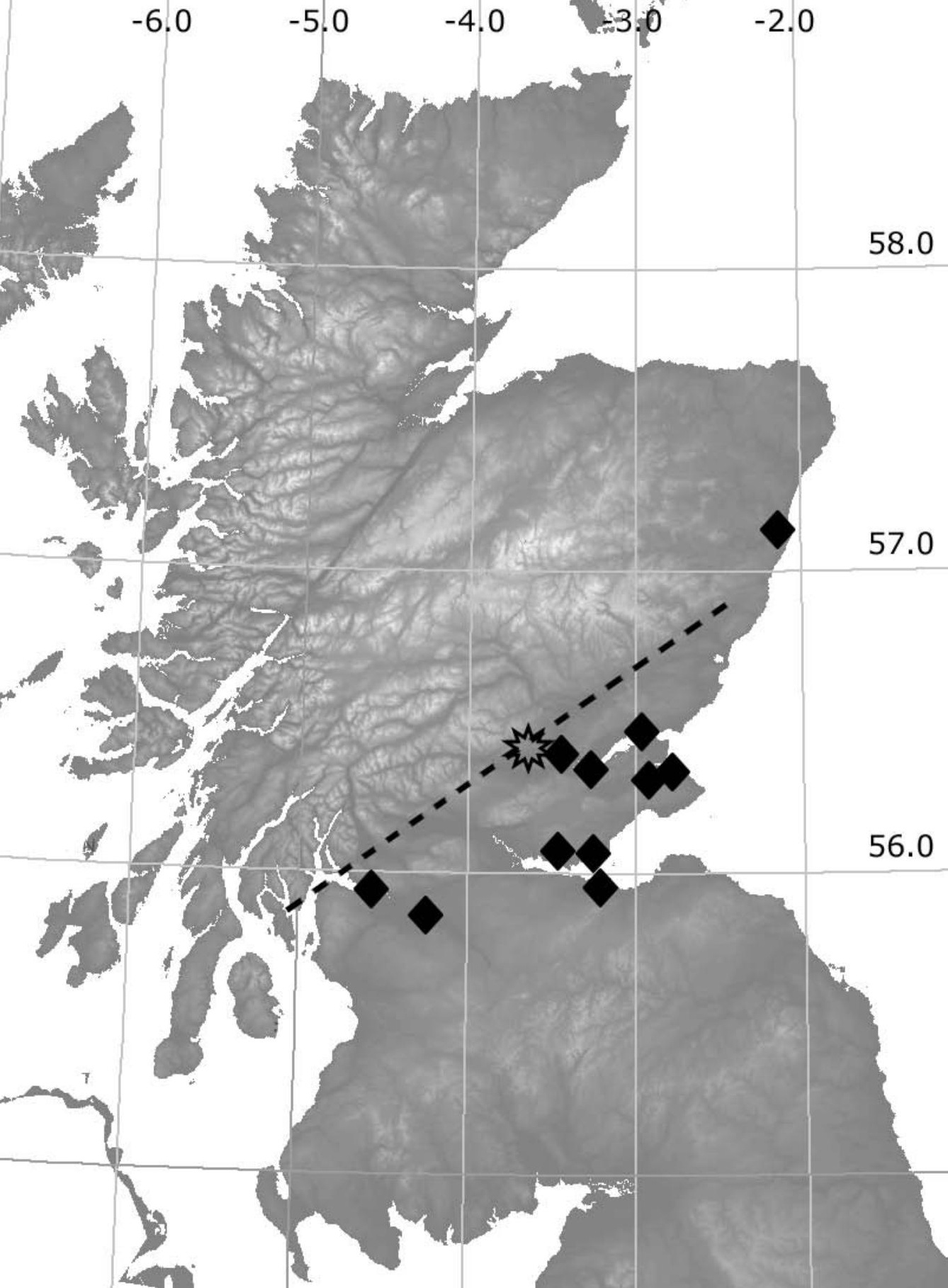




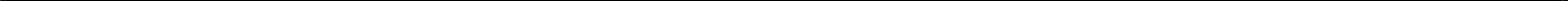




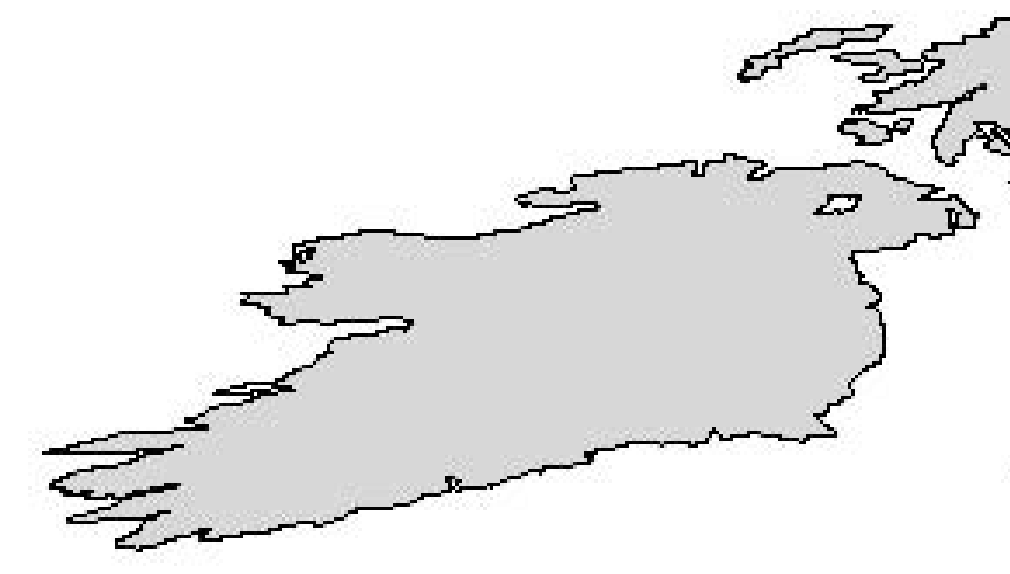

م
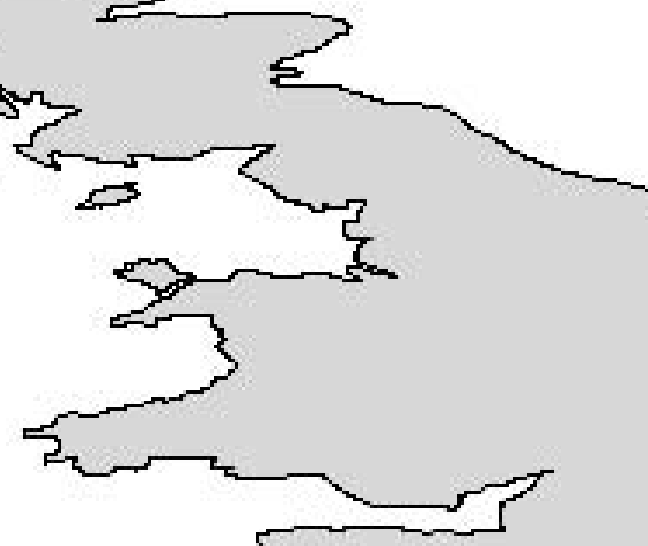

Scilly Isles

*?

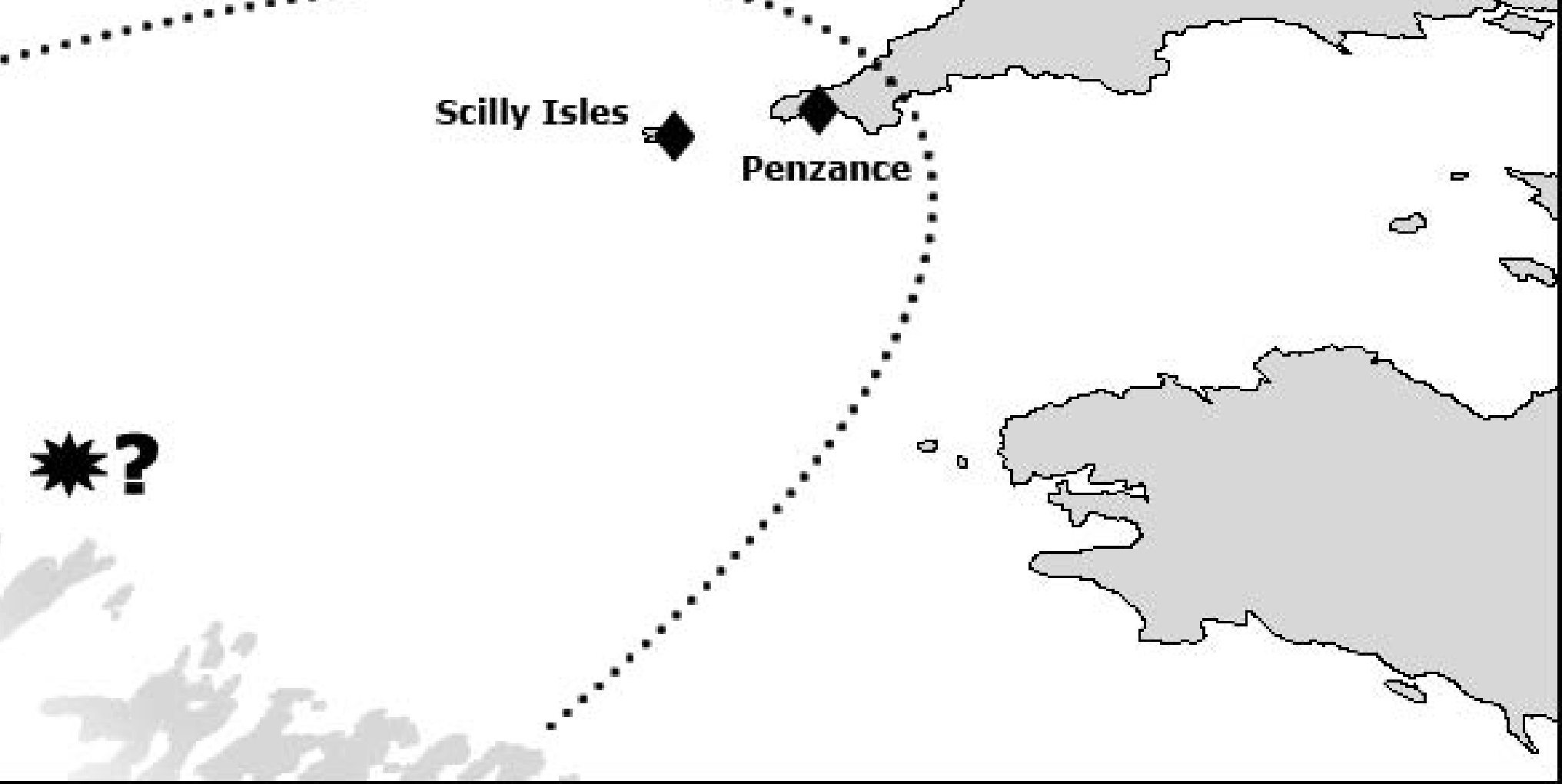

